\title{
Effect of pH on the Dye Absorption of Jute Fibre Dyed with Direct Dyes
}

\section{IBRAHIM H. MONDAL* and MD. KHADEMUL ISLAM}

Polymer and Textile Research Lab., Department of Applied Chemistry and Chemical Engineering, Rajshahi University, Rajshahi-6205, Bangladesh.

${ }^{*}$ Correponding author E-mail: mihmondal@yahoo.com

http://dx.doi.org/10.13005/ojc/300416

(Received: September 06, 2014; Accepted: October 15, 2014)

\section{ABSTRACT}

\begin{abstract}
Dyeing of direct dyes, viz. Direct Yellow 29, Direct Orange 31 and Titan Yellow, has been carried out on jute fibre in the presence of sodium sulphate as an electrolyte. The effect of $\mathrm{pH}$ on dyeing have been studied and the results showed comparatively better dye uptake at $\mathrm{pH}$ 8.0. Assesment of light and wash fastness, acid and alkali spottings, and breaking strength of direct dyed jute fibre was carried out. Direct Orange 31 showed comparatively better fastness properties than other dyes.
\end{abstract}

Key words: Jute fibre, Dyeing, Light fastness, Breaking strength and Direct dye.

\section{INTRODUCTION}

Jute dyeing is a major problem in jute trade since it has an affinity for a wider range of dyestuffs due to its structural peculiarities. Jute is dyed, generally, in order to enhance its pleasing appearance by the attraction of hue and that the hue should be uniform over the whole. Dyeing does not mean only to impart attractive hue on the fibre, but to attain fast colour on it.

Depending on the demand of jute and jute products, dyeing technology of jute did not progress like other textile fibres. Due to structural peculiarities of jute, it is very difficult to obtain proper shade, correct hue and fast colour. Some investigators ${ }^{1-5}$ describe the general methods of dyeing with different types of dyestuffs on jute fibre, but almost none of them tried to see the effect of $\mathrm{pH}$ of dye bath on dyeing.

In the present investigation, an effort has been exerted to dye bleached and raw jute fibres with direct dyes and to find out the optimum effect of $\mathrm{pH}$ of dye bath on dyeing. An assessment of light fastness, wash fastness, etc. and measurement of breaking strength of dyed jute fibre has been carried out. 


\section{EXPERIMENTAL}

\section{Materials}

Corchorus olitorius (Tossa) variety of jute fibre was supplied by Rajshahi Jute Mills, Ltd., Bangladesh. The jute fibre was washed with $6.5 \mathrm{gm}$ soap flake and $3.5 \mathrm{gm}$ soda per litre $^{6}$ and then bleached with hydrogen peroxide ${ }^{7}$. Direct Yellow 29 (C.I. 19556), Direct Orange 31 (C.I. 23655) and Titan Yellow (Direct Yellow 9, C.I. 19540). Direct dyes were purchased from BDH, England. Sodium sulphate, soda ash, soap, acetic acid and hydrogen peroxide were used of reagent grade.

\section{Method of dyeing}

Jute fibre was dyed with $2 \%$ direct dyes in the presence of sodium sulphate as electrolyte at $100^{\circ} \mathrm{C}$ for $1 \mathrm{~h}$ in the fibre-liquor ratio $1: 40$. The $\mathrm{pH}$ of the dye bath was adjusted separately to 4, 7, 8 and 10 by the addition of acetic acid and soda ash, respectively. After dyeing, the fibre was rinsed thoroughly in the cold water, squeezed and soaped for $20 \mathrm{~min}$. at $80^{\circ} \mathrm{C}$ in a dye bath containing $2 \mathrm{gm} /$ litre soap. It was then rinsed and dried. The amount of dye uptake by the jute fibre was determined by using a Spectrophotometer.

\section{Colour fastness test}

Colour fastness of dyed fibre was measured by Grey scale ${ }^{8}$. Fastness grade 5 is the control.

\section{Determination of light fastness}

The light fastness of the direct dyed jute fibre was determined by a Xenotester using xenon arc lamp (Xenotest 150 S of W. C. Heracus GmBh, Germany) under the following conditions: relative humidity, $78 \%$; black panel temperature, $45^{\circ} \mathrm{C}$, radiation genarated, Xenon burner surrounded by an optical filter system; and exposure period, $60 \mathrm{~h}$.

\section{Determination of wash fastness}

Wash fastness of direct dyed jute fibre was determined using $5 \mathrm{gm} /$ litre soap solution $^{9}$.

\section{Determination of colour fastness to spottings with acid and alkali}

Direct dyed jute fibres were combed and compressed enough to form a sheet of $10 \mathrm{~cm} \mathrm{X} 4$ $\mathrm{cm}$. The specimen was spotted with two drops of sulphuric acid (50 gm/litre), acetic acid (300 gm/ litre), tartaric acid ((100 gm/litre), sodium carbonate (100 gm/litre), sodium hydroxide (50 gm/litre) and $10 \%$ ammonia solution at room temperature ${ }^{10,11}$. The specimen was dried at room temperature and then the change in colour of the specimen was assessed with the Grey scale.

\section{Measurement of breaking strength}

Breaking strength of the direct dyed jute fibre was measured with a Tensile strength tester (Torsees Schooper-type-OS-100, Strip method) 12.

\section{RESULTS AND DISCUSSION}

\section{Effect of pH}

The dye uptake of bleached and raw jute fibres dyed with Direct Yellow 29, Direct Orange 31 and Titan Yollow from the dye bath at different $\mathrm{pH}$, viz. 4.0, 7.0, 8.0 and 10.0 are listed in Table 1. Table 1 shows the percent dye uptake by both bleached and raw jute fibres increases with the increase of $\mathrm{pH}$ upto 8.0 and beyond which the percent dye uptake decreases. The possible explanation is that jute fibre acquires a negative charge when immersed in water. Conversely, the negative charge ions of a direct dye in solution will be repelled by the surface potential of cellulose and this potential barrier will have to be overcome before the ions can enter the fibres. Increase of $\mathrm{pH}$ by addition of soda ash and electrolyte lowers the repulsion due to the similar charges between the charged fibre surface and coloured dye anions by imparting oppositely charged ion with the charged dye anion, thus by overcoming the potential barrier, improve dyeability ${ }^{13,14}$. It is observed from the Table 1 that the percent dye uptake of bleached jute fibre is comparatively higher than that of raw jute fibre. This is probably due to increase in free carboxyl content in the jute fibre on bleaching. The positively charged sodium ions of electrolyte and soda ash can be attracted toward the negatively charged surface of bleached jute fibre, and hence, neutralize of some of its repulsive effect towards anions. Thus the dye anions are present in the solution are enable to approach and enter the fibres more readily ${ }^{14}$.

\section{Light fastness}

From the Table 2, it is seen that Direct 
Table 1: Dye uptake of jute fibre dyed with direct dyes under different $\mathrm{pH}$ of dye baths

\begin{tabular}{|c|c|c|c|c|c|c|c|c|}
\hline \multirow[t]{3}{*}{$\mathrm{pH}$ of dye bath $\rightarrow$} & \multicolumn{8}{|c|}{ Dye uptake, \% } \\
\hline & \multicolumn{4}{|c|}{ Bleached jute fibre } & \multicolumn{4}{|c|}{ Raw jute fibre } \\
\hline & 4.0 & 7.0 & 8.0 & 10.0 & 4.0 & 7.0 & 8.0 & 10.0 \\
\hline Direct Yellow 29 & 40.5 & 65.0 & 78.4 & 71.5 & 36.9 & 61.0 & 72.4 & 69.7 \\
\hline Direct Orange 31 & 45.0 & 70.2 & 80.5 & 76.1 & 40.2 & 67.8 & 78.5 & 75.2 \\
\hline Titan yellow & 20.5 & 32.1 & 46.0 & 37.5 & 17.7 & 28.6 & 37.8 & 35.0 \\
\hline
\end{tabular}

Orange 31 exhibits very good colour fastness with both bleached and raw jute fibres and Direct Yellow 29 and Titan yellow exhibit good colour fastness with bleached jute fibre only on exposure to light. All dyes do not possess the same degree of fastness to light on jute. Again, the different assistants used in dyeing have a marked effect on the colour fastness of the fibre and may tend to minimize or accentuate the apparent fatting of due stuffs. It is observed from Table 2 that light fastness of dyed bleached jute fibre is comparatively better than that of dyed raw jute fibre. The possible explanation is that the raw jute contains high amount of lignin than bleached jute fibre. The exposed dyes gain sensitivity action on photooxidation process which is initiated by lignin in presence of light and it causes the rapid change in colour of dyed fibre ${ }^{15}$.

Table 2: Light fastness of jute fibre dyed with direct dyes

\begin{tabular}{|c|c|c|c|c|c|c|}
\hline \multirow[t]{3}{*}{ Exposure period, hr } & \multicolumn{6}{|c|}{ Light fastness grade } \\
\hline & \multicolumn{3}{|c|}{ Bleached jute fibre } & \multicolumn{3}{|c|}{ Raw jute fibre } \\
\hline & $\begin{array}{c}\text { Direct } \\
\text { Yellow } 29\end{array}$ & $\begin{array}{c}\text { Direct } \\
\text { Orange } 31\end{array}$ & $\begin{array}{c}\text { Titan } \\
\text { yellow }\end{array}$ & $\begin{array}{c}\text { Direct } \\
\text { Yellow } 29\end{array}$ & $\begin{array}{c}\text { Direct } \\
\text { Orange } 31\end{array}$ & $\begin{array}{c}\text { Titan } \\
\text { yellow }\end{array}$ \\
\hline 0 & 5 & 5 & 5 & 5 & 5 & 5 \\
\hline 60 & 4 & $4-5$ & 4 & 3 & 4 & 3 \\
\hline
\end{tabular}

Wash fastness

It is seen from the Table 3 that the wash fastness of Direct Orange 31 dyed jute fibre exhibits good. This supports the strong and stable dye-fibre covalent linkage. It is observed from the Table that wash fastness of dyed bleached jute is comparatively better than that of dyed raw jute.

Table 3: Wash fastness of jute fibre dyed with direct dyes

\begin{tabular}{|c|c|c|c|c|c|c|}
\hline \multirow{3}{*}{$\begin{array}{l}\text { Washing temp } \\
{ }^{\circ} \mathrm{C}\end{array}$} & \multicolumn{6}{|c|}{ Light fastness grade } \\
\hline & \multicolumn{3}{|c|}{ Bleached jute fibre } & \multicolumn{3}{|c|}{ Raw jute fibre } \\
\hline & $\begin{array}{c}\text { Direct } \\
\text { Yellow } 29\end{array}$ & $\begin{array}{c}\text { Direct } \\
\text { Orange } 31\end{array}$ & $\begin{array}{c}\text { Titan } \\
\text { yellow }\end{array}$ & $\begin{array}{c}\text { Direct } \\
\text { Yellow } 29\end{array}$ & $\begin{array}{c}\text { Direct } \\
\text { Orange } 31\end{array}$ & $\begin{array}{c}\text { Titan } \\
\text { yellow }\end{array}$ \\
\hline 0 & 5 & 5 & 5 & 5 & 5 & 5 \\
\hline 100 & 3 & $4-5$ & 4 & $2-3$ & $3-4$ & 3 \\
\hline
\end{tabular}




\section{Fastness to acid and alkali spottings}

The data on colour fastness to acid and alkali spottings of jute fibre dyed with direct dyes are presented in Table 4. It is observed from the Table that the colour fastness to spotting of dyed bleached jute fibre with acetic acid, tartaric acid and ammonium hydroxide shows excellent results. Again, the colour fastness to spotting of dyed bleached jute fibre is comparatively better than that of dyed raw jute fibre.

Table 4: Colour fastness and change in colour of jute fibre dyed with direct dyes to acid and alkali spottings

\begin{tabular}{|c|c|c|c|c|c|c|}
\hline \multirow[t]{3}{*}{ Chemicals } & \multicolumn{6}{|c|}{ Fastness grade and colour } \\
\hline & \multicolumn{3}{|c|}{ Bleached jute fibre } & \multicolumn{3}{|c|}{ Raw jute fibre } \\
\hline & $\begin{array}{c}\text { Direct } \\
\text { Yellow } 29\end{array}$ & $\begin{array}{c}\text { Direct } \\
\text { Orange } 31\end{array}$ & $\begin{array}{c}\text { Titan } \\
\text { yellow }\end{array}$ & $\begin{array}{c}\text { Direct } \\
\text { Yellow } 29\end{array}$ & $\begin{array}{c}\text { Direct } \\
\text { Orange } 31\end{array}$ & $\begin{array}{c}\text { Titan } \\
\text { yellow }\end{array}$ \\
\hline Unspotted & 5 & 5 & 5 & 5 & 5 & 5 \\
\hline Sulphuric acid & Black & 3 & 2 & Black & $2-3$ & 2 \\
\hline Acetic acid & 5 & 5 & 4 & 3 & 4 & 3 \\
\hline Tartaric acid & 4 & 5 & 4 & 3 & $3-4$ & 3 \\
\hline Sodium hydroxide & 4 & $4-5$ & 3 & 3 & 4 & $3-4$ \\
\hline Sodium carbonate & $4-5$ & 5 & 4 & $3-4$ & 4 & 4 \\
\hline Ammonium hydroxide & 5 & 5 & 5 & $4-5$ & $4-5$ & $4-5$ \\
\hline
\end{tabular}

\section{Breaking strength}

From the Table 5, it is observed that the breaking strength of direct dyed bleached and raw jute fibre decreases with increasing the exposure time. It is seen from the Table 5 that the loss in breaking strength of dyed raw jute is comparatively higher than that of dyed bleached jute. This is due to the presence of higher lignin in raw jute ${ }^{15}$.

Table 5: Loss in breaking strength of jute fibre dyed with direct dyes on exposure to light

\begin{tabular}{|c|c|c|c|c|c|c|}
\hline \multirow{3}{*}{$\begin{array}{l}\text { Exposure period, } \\
\mathrm{hr}\end{array}$} & \multicolumn{6}{|c|}{ Fastness grade and colour } \\
\hline & \multicolumn{3}{|c|}{ Bleached jute fibre } & \multicolumn{3}{|c|}{ Raw jute fibre } \\
\hline & $\begin{array}{c}\text { Direct } \\
\text { Yellow } 29\end{array}$ & $\begin{array}{c}\text { Direct } \\
\text { Orange } 31\end{array}$ & $\begin{array}{c}\text { Titan } \\
\text { yellow }\end{array}$ & $\begin{array}{c}\text { Direct } \\
\text { Yellow } 29\end{array}$ & $\begin{array}{c}\text { Direct } \\
\text { Orange } 31\end{array}$ & $\begin{array}{c}\text { Titan } \\
\text { yellow }\end{array}$ \\
\hline 0 & 39.20 & 36.50 & 38.50 & 37.00 & 34.80 & 37.20 \\
\hline 60 & 32.35 & 30.67 & 31.25 & 28.60 & 26.00 & 27.00 \\
\hline \multicolumn{7}{|c|}{ Loss in breaking strengh, \% } \\
\hline & 17.47 & 15.97 & 18.83 & 22.70 & 25.29 & 27.42 \\
\hline
\end{tabular}

\section{CONCLUSIONS}

On the basis of results obtained from the investigations, the following conclusions may be drawn:

1. Dye uptake by jute fibre increases with the increase of $\mathrm{pH}$ to a certain value and then decreases with further increase of $\mathrm{pH}$. So,
$\mathrm{pH}$ has a great effect on dye absorption of jute fibre. Again, bleached jute fibre absorbs higher amount of dye than that of raw jute.

2. The colour of dyed jute fibre become fade on exposure to light and on washing with soap solution. Light and wash fastnesses of dyed bleached jute fibre is comparatively better than that of dyed raw jute fibre. The effects of 
acid and alkali on dyed jute fibre are satisfactory in most of the cases, but in some cases it gives unwanted results by fading or changing colour.

3. The loss in breaking strength of dyed bleached jute fibre is comparatively lower than that of dyed raw jute fibre. The lower loss in breaking strength of dyed bleached jute fibre is due to the lower amount of lignin present in it.

\section{REFERENCES}

1. Patro, P. S., Text. Dyer Print. 1971, 4(8), 57.

2. Carter, D., J. Text. Inst. 1939, 30, T328.

3. Mondal, Md. I. H., Farouqui, F. I. and Chowdhury, A. K., Bangladesh J. Sci. Ind. Res. 1991, 25(1-4), 117.

4. Mondal, Md. I. H. and Farouqui, F. I., Text. Dyer Print. 23(4), 23, 1990.

5. Mondal, Md. I. H. and Farouqui, F. I., Text. Asia 1990, 21(1), 69.

6. Mondal, Md. I. H. and Farouqui, F. I., The Rajshahi Univ. Studies, Part-B 1989, 17, 1,.

7. Chatterjee, H. and Pal, K. B., J. Soc. Dyer Cols. 1955, 71, 525.

8. International Standard ISO 105-AO21978(E): Grey scale for assessing change in colour.
9. International Standard ISO 105-CO11982(E): Colour fastness to washing: Test 1.

10. International Standard ISO 105-EO51978(E): Colour fastness to spotting: Acid

11. International Standard ISO 105-EO61978(E): Colour fastness to spotting: Alkali.

12. International Standard ISO 5081-1977(E): Determination of breaking strength and elongation (Strip method)

13. Vickerstaff, T., in The Physical Chemistry of Dyeing, Imperial Chemical Industries Ltd., London, 1954, p. 234.

14. Cockett, S. R. and Hilton, K., in Dyeing of Cellulosic Fibres and Related Process, Leonard Hill (Books) Ltd., 1961, p. 214.

15. Egerton, G. S., J. Soc. Dyers Cols. 1949, 63, 764. 